\title{
THE INFLUENCE OF BTEX LANDFILL GAS EMISSIONS: A CASE STUDY OF RESIDENTS IN ROODEPOORT, GAUTENG, SOUTH AFRICA
}

\author{
SARAH ROFFE, RAEESA MOOLLA \& STEFAN GRAB \\ School of Geography, Archaeology and Environmental Studies, University of the Witwatersrand, South Africa
}

\begin{abstract}
Landfills produce pollutants that negatively impact humans and the environment. In developing countries such as South Africa, landfilling is the most common form of solid waste management. People living in close proximity to landfills are particularly at risk to harmful pollutants such as volatile organic compounds (VOCs). Although VOCs only constitute $\sim 1 \%$ of landfill gas (LFG) emissions, they are of concern as the risk associated with these pollutants is high. Of particular concern within the VOCs, is the BTEX group (viz. benzene, toluene, ethyl benzene and xylenes). These pollutants are wind dispersed to surrounding residential areas, exposing residents to hazardous gases. BTEX LFG emissions were quantified and spatially mapped using Radiello Passive Samplers (analysed by a GC with built-in FID) in residential areas around a landfill in Roodepoort, South Africa. The BTEX levels ranged from 8.83 to $39.62 \mu \mathrm{g} . \mathrm{m}^{-3}$. The effect of the slow south to south-westerly wind speeds of $\sim 2.44 \mathrm{~m} . \mathrm{s}^{-1}$, the valley terrain, and the location of the landfill resulted in a BTEX 'hotspot' north and east of the landfill site. Combined with the passive sampling strategy, a study on residents perceptions revealed that residents were concerned with this 'hotspot' area and linked it to the landfill site. They were furthermore concerned with the landfill's associated pollution and odours. It was concluded that residents living closer to the landfill were at higher risk to BTEX, especially during the winter season. Future work should include sampling at the landfill site, specifically over different time frames to include seasonality, and possibly using different sampling methods.
\end{abstract}

Keywords: VOCs, BTEX, landfill gas, perceptions, spatial distribution.

\section{INTRODUCTION}

With a global increase in urbanisation there has been an overall deterioration of urban air quality (Fenger [1]). Of urban air pollutants, aromatic hydrocarbons emitted from a number of sources are particularly hazardous to environmental health (viz. as a contribution to tropospheric ozone formation and photochemical smog) and human health (for example, benzene is a carcinogen) (WHO [2], Durmusoglu et al. [3]). BTEX emissions (i.e. benzene, toluene, ethylbenzene and xylenes), specifically, account for $20-40 \%$ of urban VOCs (Zalel and Broday [4]). The dominant sources of urban BTEX emissions range from vehicular traffic emissions (Gallego et al. [5]), building renovations (Huang et al. [6]), vaporization of fuel (Edokpolo et al. [7]), coal-fired power stations (Lourens et al. [8]) and municipal solid waste (MSW) landfill sites (Moolla et al. [9]). Of these, vehicle emissions from road traffic are reported as the most common urban air BTEX emissions (Terrés et al. [10]). With increasing levels of urbanisation and population growth, there is a greater amount of waste generated and in turn MSW landfills are growing and becoming significant BTEX sources (WHO [11], Al-Khatib et al. [12]). During a landfill's lifecycle, it emits pollutant compounds (WHO [2], Durmusoglu et al. [3]), the most toxic being the non-methane VOCs and the hazardous air pollutants (HAPs), of which the BTEX group falls within (WHO [2], Palmiotto et al. [13]). Many MSW landfill sites are in close proximity to residential areas (Al-Khatib et al. [12]), thus people living near or downwind to landfill sites are potentially at risk to these toxic emissions (Davoli et al. [14], Chiriac et al. [15]). Furthermore, dispersed LFG emissions are associated with uncomfortable odours that may stimulate public concern 
(Palmiotto et al. [13], De Feo et al. [16]). Thus, there are growing health concerns amongst residents living near landfill sites, making it imperative to monitor areas that surround major landfills.

The level of toxic effect associated with BTEX is globally well known, yet, data for South Africa is limited to a few studies (for example: Lourens et al. [8], Moolla et al. [9], Moolla et al. [17], Moolla et al. [18]). Moreover, there is little legislation regulating BTEX emissions into the atmosphere in South Africa (DEA [19]). To this end, we aim to explore residents' awareness and perceptions regarding the spatial distribution, health implications and odours associated with BTEX LFG emissions from a landfill in Roodepoort, South Africa.

\section{BACKGROUND}

Landfilling is the preferred method of waste management in South Africa and is controlled by the National Waste Management Strategy and the National Environmental Management: Waste Act (Act 59 of 2008) (NEMWA). South African waste management strategies are ahead of most developing countries, in terms of landfill site classification and waste type accepted at a particular type of landfill. Strategies are, however, not effective for LFG management practices. Consequently, LFG emissions are emitted to adjacent surroundings with little to no monitoring occurring. Within NEMWA, waste disposal site locations are to be close enough to the serviced population to prevent high transport costs, and they are to be selected to ensure accessibility and acceptance by the community. These sites are not to interfere with pedestrian movement, create an eyesore, or a public nuisance of odour. Even with these rulings in place, there are landfill sites within very close proximity to residential areas, and which are a cause of health and odour concerns.

\subsection{Site description}

The Allen's Nek and Panorama Residential areas, in the Roodepoort area, located in the Greater Johannesburg region of South Africa, are in close proximity to a MSW landfill site. These areas were the basis of the monitoring campaign for the emission and perception study (Fig. 1). To the northeast and east of the landfill is the Panorama area and to the southwest is the Allen's Nek residential area. This study area is characterised by a valley and steep-sided ridge behind Allen's Nek, then rising slightly in Panorama; the landfill is located along the valley floor. This landfill is a composting site which collects garden refuse, paper, glass, plastic, cans, motor car oil, e-waste and green waste.

\section{METHODOLOGY}

Active and passive sampling is available for monitoring ambient BTEX concentrations (e.g. Zou et al. [20]). The success of passive sampling has been noted in previous studies (e.g. Roukos et al. [21], Zabiegała et al. [22], Roukos et al. [23]); hence, using a Radiello Passive Sampling strategy for this sampling campaign was ideal. The sampler measures ambient concentrations as a weighted average over a specific sampling time using a diffusion technique based on Fick's law of diffusion (Minguy et al. [24]). A limitation of these samplers is that changing wind speeds and temperatures alter their uptake rate (Zabiegała et al. [22]). These samplers are advantageous over active samples as they are cost effective, require no external energy source and are user friendly in any environment (Kerchich and Kerbachi [25], Król et al. [26]). Each sampler consists of an absorbing cartridge inside a microporous polyethylene diffusive body supported on a triangular polycarbonate plate (Kerchich and Kerbachi [25], Król et al. [26]). Each absorbing cartridge 
has a detection limit, with lowest measurable concentrations as follows: benzene $(0.2 \mu \mathrm{g})$, toluene $(0.23 \mu \mathrm{g})$, ethyl benzene $(0.26 \mu \mathrm{g})$ and xylene $(0.24 \mu \mathrm{g})$.

Ten passive samplers were placed within the study area, from 27 July to 5 August 2015 (Fig. 1) (with an error magnitude of $<0.1 \mu \mathrm{g} \cdot \mathrm{m}^{-3}$ ). The winter period was chosen as a stable atmosphere and lower temperatures promote BTEX accumulation within the boundary layer (Kim and Kim [27]). In addition, given that this is the dry season, it reduced the risk of sampling disturbance by precipitation (Moolla et al. [9], Moolla et al. [17]). Each sampler was placed at a height of $1.5 \mathrm{~m}$ above the ground surface. After exposure the samples were collected, labelled (no leaded pencil) with their sampling times and sealed in a dark, cool box $\left(<5^{\circ} \mathrm{C}\right)$, and analysed by ChemTech laboratory using a GC with built-in FID (Gallego et al. [5], Kerchich and Kerbachi [25]).

The time-weighted average BTEX concentration $\mathrm{C}\left(\mu \mathrm{g} \cdot \mathrm{m}^{-3}\right)$ for each passive sampler was calculated according to the following equation: $C=\frac{M \times t}{Q_{t}} \times 10^{6}$, where $M$ is mass of analyte

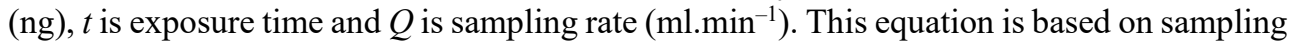
at standard conditions (298 K and $1013 \mathrm{hPa}$ ) (Kerchich and Kerbachi [25], Król et al. [26]). Since temperature and pressure would have deviated from standard conditions during the sampling campaign, the $\mathrm{Q}\left(\mathrm{ml} \cdot \mathrm{min}^{-1}\right)$ values have been corrected using the following

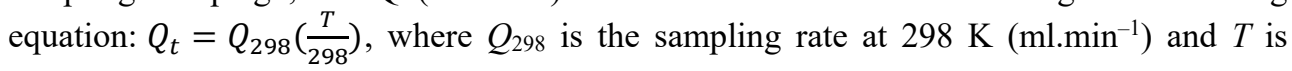
temperature in K (Kerchich and Kerbachi [25], Król et al. [26]).

The monitored measurements were used for spatial mapping of BTEX (e.g. Terrés et al. [10], Roukos et al. [21], Zabiegała et al. [22], Roukos et al. [23]); to create a raster surface using Kriging (Zabiegała et al. [22]).

Additionally, a Davis weather station was placed $\sim 400 \mathrm{~m}$ to the northeast of the landfill in a residential garden (point 9 in Fig. 1), to record the meteorological patterns during the sampling campaign as BTEX concentrations; passive sampling rates; and BTEX dispersion are influenced by meteorological conditions (Moolla et al. [17], Kerchich and Kerbachi [25], Król et al. [26]). Measurements of wind direction, wind speed, temperature and atmospheric pressure were recorded at 10-minute intervals throughout the entire monitoring period.

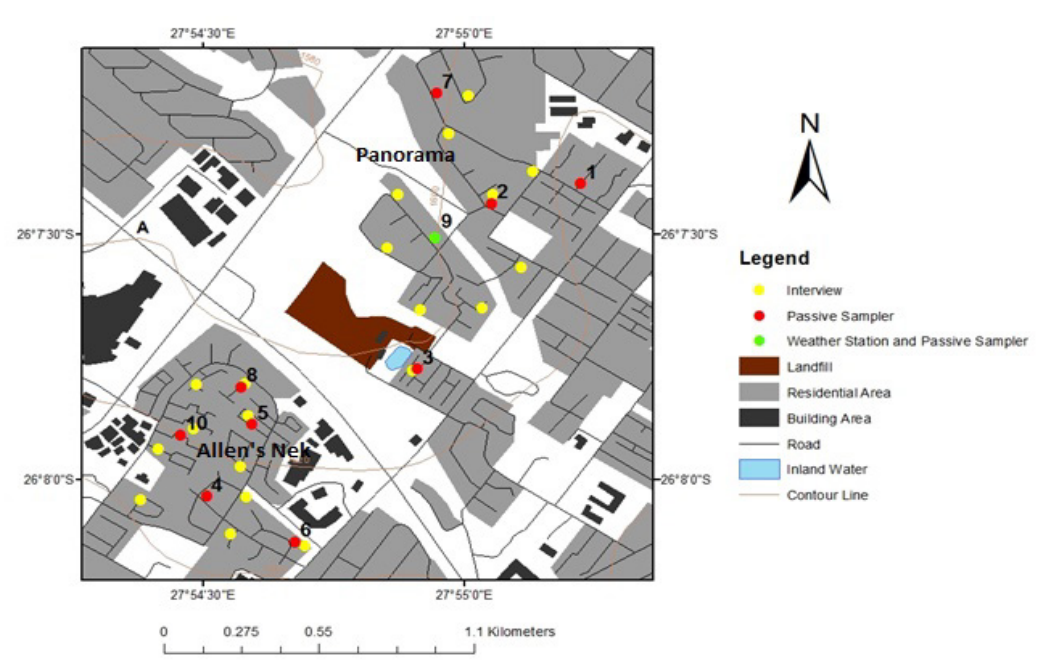

Figure 1: Data collection points in the residential areas. 
Moreover, twenty interviews (ten in each residential area) were conducted with residents, during the sampling campaign, with the aim to provide information on residents' personal attributes, perceptions, attitudes and concerns toward their surrounding environment and the landfill site (Fig. 1).

\section{RESULTS}

Mean temperature during the sampling campaign was $14.4 \pm 5.18^{\circ} \mathrm{C}$, and ranged from an absolute minimum of $4.3^{\circ} \mathrm{C}$ to an absolute maximum of $22.4^{\circ} \mathrm{C}$ (Table 1). Mean wind speed was $2.44 \pm 2.24 \mathrm{~m} . \mathrm{s}^{-1}$, and reached a maximum of $6.9 \mathrm{~m} . \mathrm{s}^{-1}$. Typical wind speeds ranged from $<1.4-3.8 \mathrm{~m} \cdot \mathrm{s}^{-1}$ and the most frequent $(32 \%)$ wind directions were south to south westerly (Fig. 2). Mean barometric pressure was $1039.62 \pm 2.04 \mathrm{hPa}$, and reflected relatively stable conditions throughout the monitoring period.

The highest concentrations of BTEX are found at passive samplers $3\left(21.13 \mu \mathrm{g} . \mathrm{m}^{-3}\right)$ and $9\left(39.62 \mu \mathrm{g} . \mathrm{m}^{-3}\right)$ (see Fig. 3 and Table 2). At passive sampler 9, the toluene concentration is extremely high $\left(26.11 \mu \mathrm{g} . \mathrm{m}^{-3}\right)$, and throughout the sampling campaign toluene is high (ranging from 3.8 to $26.11 \mu \mathrm{g} \cdot \mathrm{m}^{-3}$ ) for BTEX at all the locations, while ethyl benzene is relatively low (ranging from 0.57 to $1.92 \mu \mathrm{g} . \mathrm{m}^{-3}$ ). The BTEX concentrations for Panorama $\left(\sim 21.26 \mu \mathrm{g} . \mathrm{m}^{-3}\right)$ are considerably higher than those for Allen's Nek $\left(\sim 13.64 \mu \mathrm{g} . \mathrm{m}^{-3}\right)$.

Table 1: Meteorological conditions during the sampling campaign.

\begin{tabular}{|l|l|l|l|l|}
\hline Meteorological parameter & Min & Max & Mean & Standard deviation \\
\hline Temperature $\left({ }^{\circ} \mathrm{C}\right)$ & 4.3 & 22.4 & 14.4 & \pm 5.18 \\
\hline Wind Speed $\left(\mathrm{m} . \mathrm{s}^{-1}\right)$ & 0 & 6.9 & 2.44 & \pm 2.24 \\
\hline Barometric Pressure $(\mathrm{hPa})$ & 1020.3 & 1043.5 & 1039.62 & \pm 2.04 \\
\hline
\end{tabular}

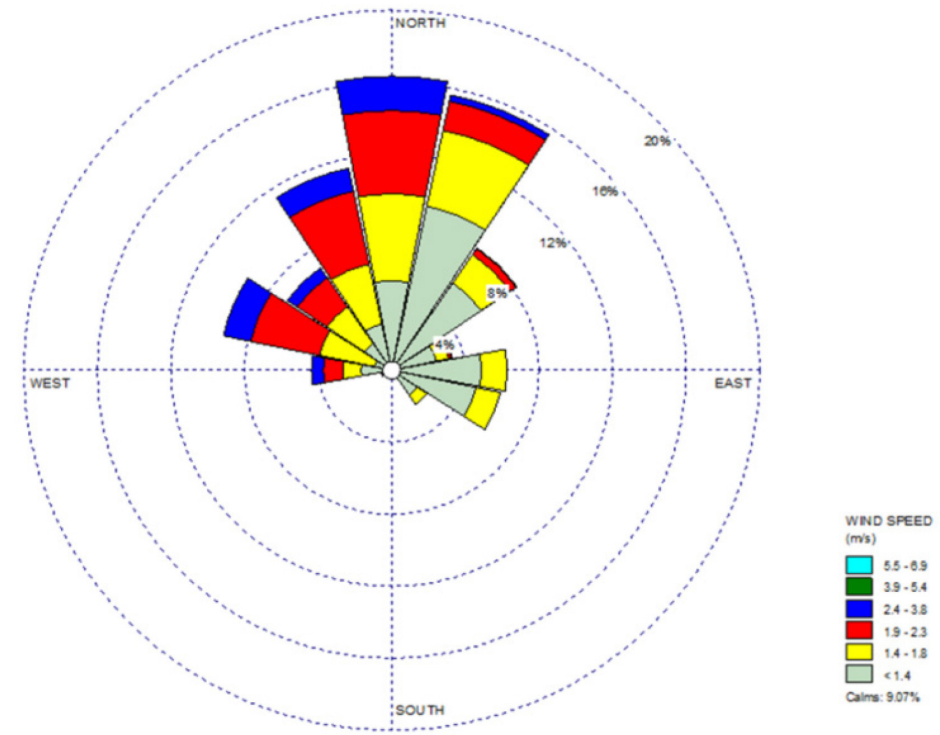

Figure 2: Wind speed and direction during the sampling campaign. Wind direction is illustrated from the centre out. 


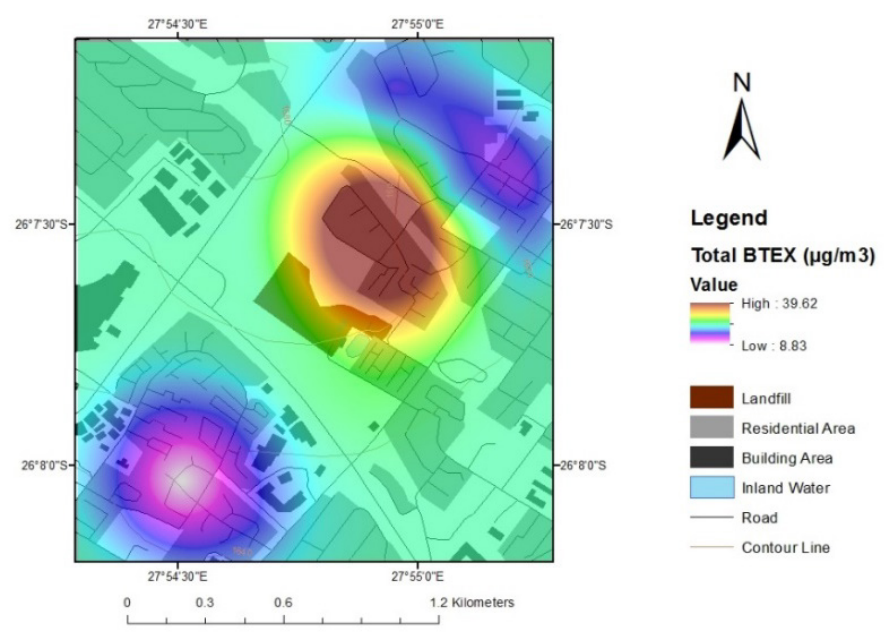

Figure 3: BTEX isoconcentration map for the sampling campaign measured in $\mu \mathrm{g} \cdot \mathrm{m}^{-3}$.

Table 2: $\quad$ BTEX concentrations $\left(\mu \mathrm{g} / \mathrm{m}^{-3}\right)$ for the Panorama (P) and Allen's Nek (AN) residential areas. Bold font indicates high values.

\begin{tabular}{|l|l|l|l|l|l|l|}
\hline Site & Passive sampler & $\begin{array}{l}\text { Benzene } \\
\left(\mu \mathrm{g} . \mathrm{m}^{-3}\right)\end{array}$ & $\begin{array}{l}\text { Toluene } \\
\left(\mu \mathrm{g} . \mathrm{m}^{-3}\right)\end{array}$ & $\begin{array}{l}\text { Ethyl benzene } \\
\left(\mu \mathrm{g} \cdot \mathrm{m}^{-3}\right)\end{array}$ & $\begin{array}{l}\text { Xylene } \\
\left(\mu \mathrm{g} \cdot \mathrm{m}^{-3}\right)\end{array}$ & $\begin{array}{l}\text { BTEX } \\
\left(\mu \mathrm{g} \cdot \mathrm{m}^{-3}\right)\end{array}$ \\
\hline $\mathrm{P}$ & 1 & 2.91 & 5.23 & 1.17 & 4.19 & 13.50 \\
& 2 & 3.09 & $\mathbf{9 . 1 1}$ & 1.15 & 4.55 & 17.90 \\
& 3 & $\mathbf{4 . 2 0}$ & $\mathbf{7 . 3 7}$ & $\mathbf{1 . 8 9}$ & $\mathbf{7 . 6 7}$ & $\mathbf{2 1 . 1 3}$ \\
& 7 & 2.97 & 5.43 & 1.38 & 4.35 & 14.13 \\
& 9 & $\mathbf{5 . 0 0}$ & $\mathbf{2 6 . 1 1}$ & $\mathbf{1 . 9 2}$ & $\mathbf{6 . 5 9}$ & $\mathbf{3 9 . 6 2}$ \\
\hline $\mathrm{AN}$ & 4 & 2.23 & 3.80 & 0.57 & 2.23 & 8.83 \\
& 5 & 3.07 & 5.80 & 1.16 & 4.84 & 14.87 \\
& 6 & 3.33 & 5.52 & 1.15 & 4.72 & 14.72 \\
& 8 & 2.11 & $\mathbf{8 . 2 8}$ & 1.19 & 4.47 & 16.05 \\
& 10 & 2.85 & 5.07 & 1.23 & 4.59 & 13.74 \\
\hline
\end{tabular}

The BTEX 'hotspot' is over the section of housing northeast of the landfill, along the valley floor in Panorama (Fig. 3). There is a clear difference between BTEX concentrations within the central part of the study site, which has a noticeably high concentration (21-39 $\left.\mu \mathrm{g} \cdot \mathrm{m}^{-3}\right)$, and areas further northeast and southwest of the landfill site which have much lower concentrations $\left(8-17 \mu \mathrm{g} . \mathrm{m}^{-3}\right)$. This is similar for all BTEX compounds mapped separately in Fig. 4.

From Fig. 4(a) it is clear that the benzene 'hotspot' is over the landfill and northeast of the landfill. This 'hotspot' is along the valley floor. The concentrations for toluene are the highest (3.8 to $26.11 \mu \mathrm{g} \cdot \mathrm{m}^{-3}$ ) among the BTEX compounds measured during the sampling campaign. Interestingly, the spatial distribution of toluene (Fig. 4(b)) is that the 'hotspot' area is not above the landfill and north east, as is the case for the other compounds, but rather it is above the residential section north of the landfill. From Fig. 4(c) it is clear that ethyl benzene shows a similar spatial distribution to benzene. The concentration of ethyl benzene is noticeably lower $\left(0.57\right.$ to $\left.1.92 \mu \mathrm{g} . \mathrm{m}^{-3}\right)$ than the other BTEX compounds measured. Xylene (Fig. 4(d)) follows a similar spatial distribution to benzene and ethyl benzene. 


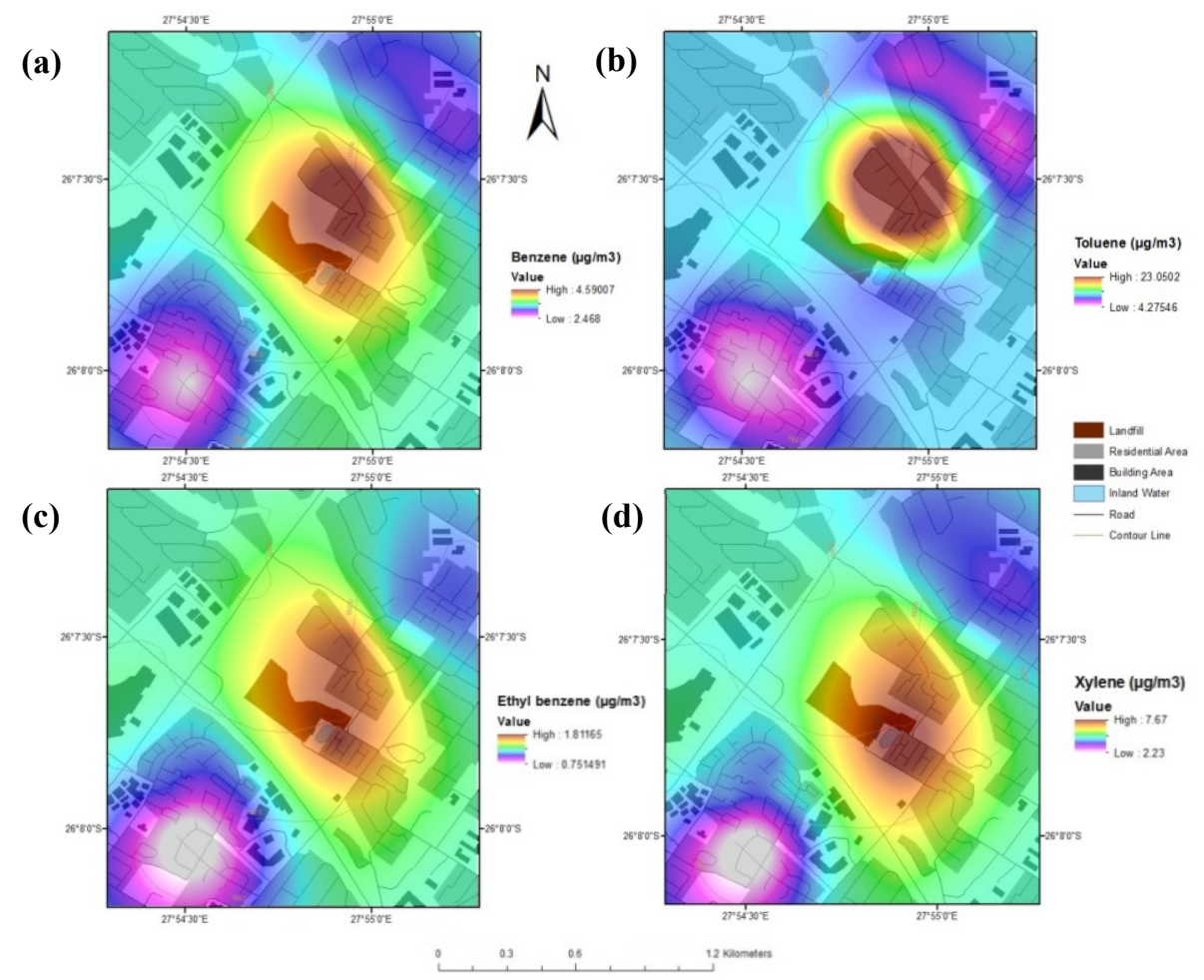

Figure 4: (a) Isoconcentration maps for Benzene; (b) Toluene; (c) Ethyl benzene; and (d) Xylene for the sampling campaign measured in $\mu \mathrm{g} . \mathrm{m}^{-3}$.

It was noted that these findings were also supported by the residents of the communities, as their responses re-iterated the 'hotspot' conditions noted through the sampling campaign. Forty percent of residents perceived the air to be 'dirty' (Fig. 5(b)). It should be noted that these residents lived within 500 meters of the landfill and had all been living in the area for over 10 years.

Resident's perceptions regarding odours in the area, specifically the odour intensity and source (Fig. 5(c)) indicated that 75\% noticed odours in the air on a regular basis; and more than half of these residents were from the Allen's Nek area. Of these residents, 50\% indicated that odours were distinct, but this time the majority of residents were from Panorama. Three main odour sources acknowledged were: the landfill site; vehicles travelling along the main roads; and the frequent fires (in the open land areas and at the landfill site). Furthermore, residents from the Panorama area confirmed that odours were mostly evident during winter, which is associated with the dominant westerlies, also noted during the sampling campaign.

In addition to the observed odours, residents were also concerned about health risks associated with these odours. Concerns for human health were mainly from residents in Panorama and included: loss of sense of smell and other sinus-related problems; headaches; itchy skin; blurry and irritated eyes; psychological illnesses; and chest problems, including asthma. Furthermore thirty five percent of residents, living within $500 \mathrm{~m}$ of the landfill site, were concerned about living near an active landfill site. They also indicated that the landfill affected the value of their property. 


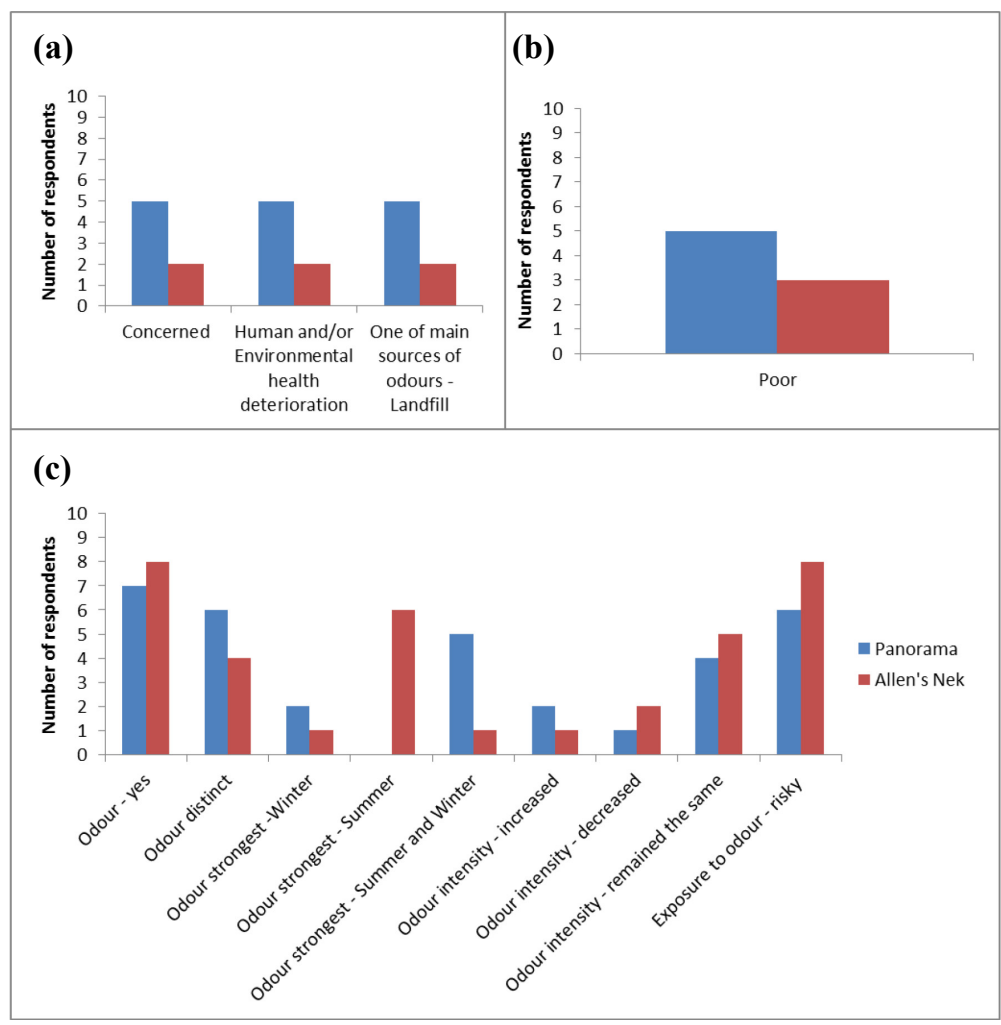

Figure 5: (a) Landfill; (b) air quality; (c) and odour perceptions of residents from Panorama and Allen's Nek residential areas.

\section{DISCUSSION}

The results obtained from the sampling campaign show clear differences between the Allen's Nek and Panorama residential areas. It is evident that this is due to a relationship between the ambient BTEX levels, terrain shape, atmospheric circulation, the landfill site location and resident's perceptions and awareness. Each of these factors plays an important role in Allen's Nek and Panorama areas. The results are discussed with regard to this composting site as a fully functional landfill.

The BTEX concentrations are comparable with other studies, however, the concentrations levels are slightly lower, where averages for BTEX during summer are relatively similar to the average of $17.45 \mu \mathrm{g} . \mathrm{m}^{-3}$ found for winter during this study (e.g. Zou et al. [20], Kim et al. [28], Ying et al. [29], Gallego et al. [30]). This can be attributed to management conditions at the composting site and waste type, as composting sites are likely to have lower BTEX rates (Durmusoglu et al. [3], Zou et al. [20]). The measured BTEX concentrations $\left(8.83-39.62 \mu \mathrm{g} \cdot \mathrm{m}^{-3}\right)$ are however, higher than those from a study conducted by Davoli et al. [14] $\left(2.05-16.81 \mu \mathrm{g} . \mathrm{m}^{-3}\right)$ in Italy for a $0.5-6 \mathrm{~km}$ radius around a landfill during winter. Again, different management practices at the landfill site may play a role as well as the presence of other pollutant sources within the sampling area (Davoli et al. [14]).

As residents spend between 10-15 hours at home daily, they are potentially exposed to these BTEX concentrations. On average each resident travels about 2-10 hours a week. 
Hence, during the majority of the day residents are exposed to BTEX from a number of sources within and outside of their residential area. More than half of the residents $(60 \%)$ had been living in the area for over 10 years. Moreover, the landfill has been open for more than 10 years; therefore, most residents have been living with a constant exposure to BTEX from the landfill site. The risk associated with this exposure according to ambient air quality standards is yet to be calculated and is for future work.

The results may be related to distance from the landfill, especially in Allen's Nek. These results agree with De Feo et al. [16] who reported less concern with increasing distance from a landfill. In Allen's Nek, there was very little concern about the landfill and the air quality within the area (Fig. 5(a) and (b)). Some residents in Allen's Nek expressed concern (Fig. 5(a)); they were, however, located just across the road from the landfill site. One noted that the odour was strong in both winter and summer and the other noted that it was strongest in winter. These residents were the only two in Allen's Nek to identify the landfill as an odour source and odours were present during winter. Exposure to odours naturally raises concern and discomfort as it did for these residents.

The resulting BTEX distribution in Allen's Nek can be attributed to a number of factors that characterise this area during winter. The wind patterns are representative of westerlies as is seen by the observed wind direction (Fig. 2), whereas for summer (as reported by $60 \%$ of residents in Allen's Nek), the wind patterns are noted to change and odours from the landfill become an issue for Allen's Nek residents as well (Fig. 5(c)). Further analysis in summer is necessary, especially since the BTEX level for summer is expected to be lower than for winter as cold temperatures allow for BTEX accumulation (Moolla et al. [17], Hoque et al. [31]).

The local terrain also has more of an effect in winter, as the mixing height for pollutants is reduced from the high pressure cell over South Africa's interior (Moolla et al. [9], Tyson and Preston-Whyte [32]). This causes pollutants to accumulate as opposed to summer when pollutants are less restricted by vertical dispersion (Tyson and Preston-Whyte [32]). The steeper valley side within Allen's Nek would, along with the observed wind patterns, force pollutants to disperse along the valley floor, especially at night, towards the Panorama area (Tyson and Preston-Whyte [32]). Thus, the BTEX 'hotspot' locations are as a result of the wind patterns, the restriction of vertical dispersion from the high pressure and the subsidence action from the valley microclimate processes.

As reported by an Allen's Nek resident: "The landfill is probably more of an issue for Panorama residents". Residents living further away from the landfill, in Panorama, reported that the landfill is an issue for those living closer to it; concern thus shows an association with distance (De Feo et al. [16], Elliot et al. [33]). These residents identified odours but didn't find these odours distinct, still most of them identified that exposure to these odours are risky to human and environmental health. Therefore, the greatest concerns came from those who can regularly smell the landfill odours and those who lived closer to the landfill (Al-Khatib et al. [12]). The valley microclimate processes, the slow wind speeds of about $\sim 2.44 \mathrm{~m} . \mathrm{s}^{-1}$ and the high pressure observed during the sampling campaign would have restricted dispersion of BTEX to that area. This is evident from the low BTEX level, Fig. 3, observed in the Panorama areas further away from the main BTEX sources, the landfill site and the main roads.

The relationship between the BTEX sources, local atmospheric circulation and terrain seem responsible for the location of BTEX 'hotspots' above the landfill and in the residential section northeast of the landfill (Figs 3 and 5). BTEX levels are usually highest near major sources and generally disperse in agreement with the prominent wind patterns and local 
terrain (Terrés et al. [10], Roukos et al. [21], Roukos et al. [23]). Thus, the BTEX levels in the Panorama area are not from transboundary pollution, but from local sources.

It was noted that a 'veld' fire (biomass burning) occurred during the sampling campaign within the open land directly behind the sampler. The 'veld' fire might be responsible for the high BTEX level as BTEX is emitted during biomass burning (Barboni and Chiaramonti [34], Barboni et al. [35]). It is evident that the BTEX rate at passive sampler 9 is the same as the BTEX rate for vehicles and landfill sites. Hence, the 'veld' fire then may only be partially responsible for the high BTEX level at sampler 9. The 'veld' fire and the observed wind patterns may be a potential reason as to why the toluene hotspot (Fig. 4(b)) is further northeast than the other 'hotspots' (Fig. 4(a), (c) and (d)).

The BTEX level is relatively high within the Panorama area. This is risky to both human and environmental health. This situation demands further analysis and particular attention from decision makers.

\section{CONCLUSIONS}

The results from the sampling campaign show that residents are influenced by the landfill site, especially in the Panorama area. Despite this influence, residents within the Allen's Nek and Panorama areas were exposed to a lower level of BTEX, than in other comparative studies. The BTEX concentrations within the study area comprised of both landfill and vehicular emissions. $35 \%$ of residents interviewed expressed concern regarding the landfill, of which $71 \%$ of these lived in Panorama within the BTEX 'hotspot' (19.81 to $39.62 \mu \mathrm{g} \cdot \mathrm{m}^{-3}$ ) and expressed the most concern regarding the air quality and odours in the air. The perceptions obtained from these residents displayed an association with distance and the number of years living in the area. The passive sampling campaign revealed that the BTEX 'hotspot' is along the valley floor in Panorama during winter. The 'hotspot' location was as a result of a relationship between the predominant south to south westerly winds averaging $2.44 \mathrm{~m} . \mathrm{s}^{-1}$, the high pressure of $\sim 1039.62 \mathrm{hPa}$ and the valley microclimatic processes during the winter season.

To reduce the influence of the landfill, residents can employ mitigation strategies such as better ventilation in houses to remove pollutants and to, especially during winter, close all south and south westerly facing windows to reduce the amount of BTEX entering their houses. Future work will need to incorporate seasonality as well as other available active sampling methods to incorporate longer/multiple sampling campaigns and sampling on the landfill site.

\section{ACKNOWLEDGEMENTS}

The authors would like to thank the ChemTech laboratory, South Africa for analysing the Radiello Passive samplers and all residents in the Panorama and Allen's Nek areas.

\section{REFERENCES}

[1] Fenger, J., Urban Air Quality. Atmospheric Environment, 33, pp. 4877-4900, 1999.

[2] WHO, Air Quality Guidelines for Europe: Second Edition, WHO Regional Publications, European Series, No. 91, 2000.

[3] Durmusoglu, E., Taspinar, F. \& Karademir, A., Health risk assessment of BTEX emissions in the landfill environment. Journal of Hazardous Materials, 176, pp. 870-877, 2010.

[4] Zalel, A.Y. \& Broday, D.M., Revealing source signatures in ambient BTEX concentrations. Environmental Pollution, 156, pp. 553-562, 2008. 
[5] Gallego, E., Perales, J.F., Roca, F.J. \& Guardino, X., Surface emission determination of volatile organic compounds (VOC) from a closed industrial waste landfill using a self-designed static flux chamber. Science of the Total Environment, 470-471, pp. 587-599, 2014.

[6] Huang, L., Mo, J., Sundell, J., Fan, Z. \& Zhang, Y., Health risk assessment of inhalation exposure to formaldehyde and benzene in newly remodelled buildings, Beijing. PLoS ONE, 8, 2013. DOI: 10.1371/journal.pone.0079553.

[7] Edokpolo, B., Yu, Q. \& Connell, D., Health risk assessment of ambient air concentrations of benzene, toluene, xylene (BTX) in service station environments. International Journal of Environmental Research and Public Health, 11, pp. 6354-6374, 2014.

[8] Lourens, A.S., et al., Spatial and temporal assessment of gaseous pollutants in the Highveld of South Africa. South African Journal of Science, 107, pp. 1-8, 2011.

[9] Moolla, R., Valsamakis, S.K., Curtis, C.J. \& Piketh, S.J., Occupational health risk assessment of benzene and toluene at a landfill site in Johannesburg, South Africa. Safety and Security Engineering V, eds F. Garzia., C.A. Brebbia and M. Guarascio, WIT Press: Southampton, pp. 701-712, 2013.

[10] Terrés, I.M.M., Miñarro, M.D., Ferradas, E.G., Caracena, A.B. \& Rico, J.B., Assessing the impact of petrol stations on their immediate surroundings. Journal of Environmental Management, 91, pp. 2754-2762, 2010.

[11] WHO, Population health and waste management: scientific data and policy options, Report of a WHO workshop, Rome, 2007.

[12] Al-Khatib, A.I., Ajlouny, H., Al-Sari, M.I. \& Kontogianni, S., Residents' concerns and attitudes toward solid waste management facilities in Palestine: A case study of Hebron District. Waste Management and Research, 32, pp. 228-236, 2014.

[13] Palmiotto, M., Fattore, E., Paiano, V., Celeste, G., Colombo, A. \& Davoli, E., Influence of a municipal solid waste landfill in the surrounding environment: Toxicological risk and odor nuisance effects. Environment International, 68, pp. 1624, 2014.

[14] Davoli, E., Gangai, M.L., Morselli, L. \& Tonelli, D., Characterisation of odourants emissions from landfills by SPME and GC/MS. Chemosphere, 51, pp. 357-368, 2003.

[15] Chiriac, R., Carré, J., Perrodin, Y., Vaillant, H., Gasso, S. \& Miele, P., Study of the dispersion of VOCs emitted by a municipal solid waste landfill. Atmospheric Environment, 43, pp. 1926-1931, 2009.

[16] De Feo, G., De Gisi, S. \& Williams, I.D., Public perception of odour and environmental pollution attributed to MSW treatment and disposal facilities: A case study. Waste Management, 33, pp. 974-987, 2013.

[17] Moolla, R., Curtis, C.J. \& Knight, J., BTEX concentrations influenced by external factors at a diesel-refuelling station in Johannesburg, South Africa. The Sustainable Cities XI, WIT Press: Southampton, pp. 1459-1467, 2014.

[18] Moolla, R., Curtis, C.J. \& Knight, J., Occupational Exposure of diesel station workers to BTEX compounds at a bus depot. International Journal of Environmental Research and Public Health, 12, pp. 4101-4115, 2015.

[19] DEA, National Environmental Management: Air Quality Act 2004, Government Gazette: South Africa, 2009.

[20] Zou, S.C., et al., Characterization of ambient volatile organic compounds at a landfill site in Guangzhou, South China. Chemosphere, 5, pp. 1015-1022, 2003. 
[21] Roukos, J., Riffault, V., Locoge, N. \& Plaisance, H., VOC in an urban and industrial harbor on the French North Sea coast during two contrasted meteorological situations. Environmental Pollution, 157, pp. 3001-3009, 2009.

[22] Zabiegała, B., Urbanowicz, M. \& Namienśnik, J., Spatial and seasonal patterns of benzene, toluene, ethylbenzene, and xylenes in the Gdańsk, Poland and surrounding areas determined using Radiello passive samplers. Journal of Environmental Quality, 39, pp. 896-906, 2010.

[23] Roukos, J., Locoge, N., Sacco, P. \& Plaisance, H., Radial diffusive samplers for determination of 8-h concentration of BTEX, acetone, ethanol and ozone in ambient air during a sea breeze event. Atmospheric Environment, 45, pp. 755-763, 2011.

[24] Minguy, A., Plaisance, H., Galloo, J.C. \& Guillermo, R., Laboratory tests for the development of a new high uptake rate passive sampler for nitrogen dioxide measurements. Transactions on Ecology, 47, pp. 501-510, 2001.

[25] Kerchich, Y. \& Kerbachi, R., Measurement of BTEX (benzene, toluene, ethybenzene, and xylene) levels at urban and semirural areas of Algiers City using passive air samplers. Journal of the Air \& Waste Management Association, 62, pp. 1370-1379, 2012.

[26] Król, S., Zabiegała, B. \& Namieśnik, J., Measurement of benzene concentration in urban air using passive sampling. Analytical and Bioanalytical Chemistry, 403, pp. 1067-1082, 2012.

[27] Kim, K. \& Kim, M., The distributions of BTEX compounds in the ambient atmosphere of the Nan-Ji-Do abandoned landfill site in Seoul. Atmospheric Environment, 36, pp. 2433-2446, 2002.

[28] Kim, K., Shon, Z.K.M., Sunwoo, Y., Jeon, E. \& Hong, J., Major aromatic VOC in the ambient air in the proximity of an urban landfill facility. Journal of Hazardous Materials, 150, pp. 754-764, 2008.

[29] Ying, D., et al., Characterization and control of odourous gases at a landfill site: A case study in Hangzhou, China. Waste Management, 32, pp. 317-326, 2012.

[30] Gallego, E., Perales, J.F., Roca, F.J. \& Guardino, X., Surface emission determination of volatile organic compounds (VOC) from a closed industrial waste landfill using a self-designed static flux chamber. Science of the Total Environment, 470-471, pp. 587-599, 2014.

[31] Hoque, R.R., Khillare, P.S., Agarwal, T., Shridhar, V. \& Balachandran, S., Spatial and temporal variation of BTEX in the urban atmosphere of Delhi, India. Science of the Total Environment, 392, pp. 30-40, 2008.

[32] Tyson, P.D. \& Preston-Whyte, R.A., The Weather and Climate of Southern Africa, Oxford University Press: Cape Town, 2000.

[33] Elliott, S.J., et al., 'It's not because you like it any better...': Residents' reappraisal of a landfill site. Journal of Environmental Psychology, 17, pp. 229-241, 1997.

[34] Barboni, T. \& Chiaramonti, N., BTEX Emissions during prescribed burning in function of combustion stage and distance from flame front. Combustion Science and Technology, 182, pp. 1193-1200, 2010.

[35] Barboni, T., Cannac, M., Pasqualini, V., Simeoni, A., Leoni, E. \& Chiaramonti, N., Volatile and semi-volatile organic compounds in smoke exposure of firefighters during prescribed burning in the Mediterranean region. International Journal of Wildland Fire, 19, pp. 606-612, 2010. 